\title{
Towards a pro-poor development strategy for middle-income countries: a comment on Bresser-Pereira and Nakano
}

\author{
Rumo a uma estratégia de crescimento favorável \\ aos pobres para países de renda media: um \\ comentário sobre Bresser-Pereira e Nakano
}

ALFREDO SAAD FILHO*

RESUMO: Este artigo baseia-se em Bresser-Pereira e Nakano (2003), a fim de delinear uma estratégia de crescimento favorável aos pobres para os países de renda média. Essa estratégia evita as armadilhas do modelo neoliberal implementado em vários países no rescaldo da crise da dívida internacional de 1982 e é propício à distribuição de renda e ao crescimento sustentável simultaneamente.

PALAVRAS-CHAVE: Política pro-pobre; neoliberalismo; macroeconomia; pobreza; riqueza.

ABSTRACT: This paper draws upon Bresser-Pereira and Nakano (2003), in order to outline a pro-poor growth strategy for middle-income countries. This strategy avoids the pitfalls of the neoliberal model implemented in several countries in the aftermath of the 1982 international debt crisis, and is conducive to income distribution and sustainable growth simultaneously.

KEYWORDS: Pro-poor policy; neoliberalism; macroeconomics; poverty; welfare.

JEL Classification: I3; H5; Z18.

In a recent issue of the Brazilian Journal of Political Economy, Bresser-Pereira and Nakano (2003) published a remarkable paper that will surely become an important reference in the contemporary Latin American economic debate. In their essay, Bresser-Pereira and Nakano cogently criticise the neoliberal ("dependent", p. 11) growth strategy of most Latin American countries in the closing years of the twentieth century, convincingly demonstrate that sustained growth must be based on domestic rather than foreign savings, and skillfully outline an alternative development strategy for middle-income countries.

\footnotetext{
* Department of Development Studies, SOAS - School of Oriental and African Studies, University of London, London, UK. E-mail: asfilho@aol.com. Submitted: July 2003; accepted: August 2003.
} 
This paper builds upon the latter feature of Bresser-Pereira and Nakano's contribution. It is clearly important to devise alternative development strategies for middle-income countries. Neoliberal programmes based upon the so-called (post-) Washington Consensus have failed throughout Latin America. Voters in several countries, including Argentina, Bolivia, Brazil, Ecuador, Venezuela and elsewhere have expressed their dissatisfaction, and in several countries the majority is clearly unwilling to bear further costs of "adjustment". In nearly every country, these costs include increased external vulnerability, slower growth, rising unemployment and a deteriorating distribution of income and wealth. However, it remains to be shown how alternative macroeconomic programmes can deliver rapid and sustained growth with poverty alleviation and distribution. Latin American political economy can offer an important contribution towards the achievement of these worthwhile objectives.

In this respect, the key insights of Bresser-Pereira and Nakano's contribution are the following:

- Middle-income countries should rely primarily on domestic rather than for-eign savings to finance investment and growth. This requires a resolution of the balance of payments, fiscal and financial constraints in these economies.

- Countries should adopt floating exchange rate regimes and avoid currencyovervaluation (exchange rate "neopopulism", pp. 18, 20). This obviously presumes that inflation can be tamed by other means.

- Foreign capital flows should be controlled in order to avoid destabilising ex-change rate movements and excessive vulnerability to sudden capital outflows. These controls should include, in different ways, foreign direct and portfolio investment, and foreign loans. In this context, governments should attempt to reduce the foreign debt/exports ratio to manageable levels (e.g., below 2).

- Finally, it is essential to achieve long-term fiscal balance in order to preventrunaway inflation and excessive (and costly) expansion of the domestic public debt. In order to achieve this objective, Bresser-Pereira and Nakano suggest the implementation of contractionary fiscal policies, "beyond the levels usually required by the IMF, together with a reduction of the domestic interest rates and currency devaluation" (p. 23). This combination of policies, and the ensuing macroeconomic stability, may allow foreign savings to contribute to sustainable domestic growth, rather than generating instability.

Most political economists will find these suggestions uncontroversial. BresserPereira and Nakano's recommendation that countries should rely primarily on domestic rather than foreign savings is supported not only by the pioneering work of Feldstein and Horioka (1980), but also by recent research by Calvo (1996) and Calvo, Leiderman and Heinhart (1996). A political economy interpretation of these findings is provided by Palma (1998). Relative undervaluation of the exchange rate 
is strongly supported by recent work on trade and industrial policy, including Agosín and Tussie (1993), Chang (1994), Gereffi and Wyman (1990) and UNDP (2003). Capital controls are advocated by Epstein, Grabel and Jomo (2003). In contrast, however, fiscal restraint is likely to be the most hotly debated aspect of BresserPereira and Nakano's suggestions. In what follows, this paper supports this particular aspect of Bresser-Pereira and Nakano's agenda. It also outlines, in further detail, possible directions for an alternative (pro-poor) economic strategy that may be implemented immediately (with suitable adaptations to local conditions) in a range of middle-income countries. This strategy draws upon the rapidly growing literature on "pro-poor growth policies" (see, for example, Cornia et al 1988, Dagdeviren et al 2002, MacEwan 1999, Rao 2002, Saad Filho 2003 and Winters 2002).

\section{TOWARDS AN ALTERNATIVE STRATEGY}

Pro-poor policies should fulfil two primary objectives. First, growth must benefit the poor more than the rich (in other words, it must reduce absolute as well as relative poverty), and lead to sustained improvements in the living standards of the majority. These outcomes must be independent from trickle-down effects, and they should be unambiguous across a broad spectrum of measures of social welfare. Second, as was mentioned above, these policies should be efficient, consistent, and sustainable. Policies that are excessively costly to implement and monitor, that generate welfare traps and disincentives, or that create macroeconomic instability are unsustainable in the long-term, and should be avoided.

A pro-poor growth strategy for middle-income countries starts by recognising the importance of growth. Economic growth contributes to poverty reduction in several ways. Growth increases the availability of goods and services and expands the country's consumption possibilities. It creates employment, expands markets and sales income, and raises wages through the creation of labour scarcities. Growth also funds social programmes and finances the provision of public goods (see below). Finally, economic growth generates the savings and the financial development required to fund investment and consumer spending. In the absence of growth (and foreign transfers, e.g., international aid), poverty-reducing outcomes must rely on distribution alone, which tends to create severe political tensions. Having said this, the success of a pro-poor strategy should not be judged by the economic growth rates alone. Rather, it should be assessed through the quality of the growth process and its outcomes. Specifically, a pro-poor strategy increases welfare and empowers the majority of the population, whereas neoliberal strategies generally lead to the opposite outcomes (this conclusion is cogently demonstrated by Bresser-Pereira and Nakano; see also Milanovic 2002).

In this context, investment is essential. Investment is the driving force of growth but, as is well known, growth is also the driving force of investment, because rapid and sustained growth generates the demand that makes individual investment projects viable. In order to kick-start this virtuous circle of growth and 
investment, the state should select priority sectors through targeted (vertical) industrial policies, and offer incentives to the expansion of capacity and output, especially in areas likely to relieve the balance of payments constraint. These policies and activities should be financed by a progressive tax system, and by the additional tax revenues generated by economic growth.

In this context, fiscal policy becomes critically important. Critics of neoliberalism often argue that alternative strategies should be based on loose fiscal, monetary and exchange rate policies. This suggestion is misguided, for three reasons. First, it draws upon a narrow reading of the experience of the United States (as well as key Western European countries) between the mid-1930s and the mid-1970s. This is largely inapplicable to middle-income countries, because of their much tighter balance of payments constraint. Specifically, developed countries could either print the world currency (especially Britain before World War II, and the US afterwards), or had much easier access to foreign currency than is currently possible for middleincome countries. Second, in semi-industrialised middle-income countries loose fiscal, monetary and exchange rate policies tend to generate unsustainable booms, which are destabilising both economically and politically. This is especially true in economies starved of investment for long periods, and where high unemployment coexists with low spare capacity in critically important industrial sectors. Third, the "fully" expansionary alternative is not politically feasible. The rapid reversal of the fiscal stance, from a surplus (or balance) to a significant deficit, is likely to trigger strong resistance from the IMF and the US Treasury Department, the local media, financial sector interests, and conservative ideologues of every stripe. This is likely to destabilise the government and demoralise the alternatives long before their expansionary implications can be felt.

It follows that the investment projects required by a pro-poor strategy must be financed adequately. This will not only avoid the difficulties outlined above, but also ensure that the liabilities of the central government (including the stock of circulating money and the domestic public debt) will not increase excessively rapidly, leading to inflation, high interest rates and high interest payments on the domestic debt. Recent experience in Latin America and elsewhere shows that these consequences of fiscal, monetary and exchange rate policy laxity eventually block economic growth, generate political instability, and make distribution very difficult.

In order to achieve the desired outcomes, fiscal policy should generally have a restrictive bias, with deficits under recessions but significant surpluses during the boom, leading to a (possibly modest) surplus over the economic cycle. BresserPereira and Nakano are correct. Furthermore, this fiscal policy stance can play a more constructive role than is generally acknowledged.

A pro-poor growth strategy should support worker representation through trade unions and impose rising minimum wages, as well as providing incentives for the payment of high and relatively equal wages within and between industries. These will be at least partly funded by high (progressive) income taxes and social security charges. These policies, together with a restrictive fiscal policy, can stimulate technical innovation and productivity growth. 
Low inflation, a relatively undervalued exchange rate and low state demand will stimulate exports rather than production for the domestic market, prevent inefficient firms from profiting systematically from price increases, and curtail their reliance upon state procurement. Moreover, state regulation and inspection will make it difficult for firms to increase profitability by cutting wages, arbitrarily extending the working day or bypassing health and safety rules. By the same token, relatively high wages across the board will guarantee extraordinary profits to those companies with the most productive techniques, while increasing the pressure on their inefficient competitors. Workers unemployed because of the unavailability of lowpaid jobs or the bankruptcy of inefficient firms should be supported and retrained with public funds. Finally, these workers may find it easier to move to other sectors of the economy if the wages are relatively equal across different industries. This will increase economic flexibility and help to reduce structural unemployment.

In this context, the choice of monetary and exchange rate policy is trivial. They should be accommodating, as is suggested by Bresser-Pereira and Nakano, in order to stimulate investment and keep the currency moderately undervalued. The potentially inflationary implications of these policies will be cancelled out by the contractionary impact of fiscal policy.

Bresser-Pereira and Nakano are correct in arguing that the balance of payments constraint must be considered carefully. The tax rates required to support pro-poor policies will necessarily be higher than abroad. Therefore, capital controls are essential not only to support domestic economic stability (as was argued above), but also to minimise capital flight. Moreover, international trade must also be regulated to the extent permissible under WTO rules (see UNDP 2003), since the international experience shows that relatively autonomous late development is possible only if domestic industry and agriculture are protected (see Amsden 1997, 2001, and Chang 2002). However, specific interventions must be justified, and progress must be checked against clear performance standards.

Finally, a pro-poor strategy necessitates specific polices to protect the poor and improve social welfare. These policies should prioritise the provision of public goods (social wage) rather than monetary handouts (although the latter should not be excluded). Programmes including the expansion of education, training and health provision, water and sanitation, parks and public amenities, state-sponsored environmental preservation programmes, staple foods, clothing, shoes and public transport, have relatively low administrative costs and they can reach the poor directly. In most middle-income countries, including Brazil, the required administrative infrastructure is already in place. In contrast, cash transfers (e.g., along the lines proposed by Suplicy 2003) are less desirable. On the one hand, they assume that social welfare is determined by the individual capacity to purchase private goods, rather than the access to public goods. On the other hand, they foster the commodification of social life and the development of competition. In contrast, a high social wage ensures the provision of key goods and services to all, contributes to the de-commodification of the social relations, and fosters human solidarity. The 
importance of these objectives is widely acknowledged, for example by the UNDP Human Development Index.

\section{CONCLUSION}

This paper has reviewed briefly the contribution of Bresser-Pereira and Nakano (2003) towards an alternative development strategy for middle-income countries, drawing upon the recent literature on pro-poor growth strategies.

Needless to say, implementation of alternative strategies depends less on their internal consistency (which has nevertheless been demonstrated above) than on political limitations. More specifically, the most important constraint preventing the introduction of pro-poor economic strategies in middle-income countries, including Argentina, Brazil, Indonesia, Thailand, Turkey and South Africa, among others, is not resource scarcity. It is, rather, the lack of political will to confront neoliberalism and build alternatives based upon the interaction between progressive governments and civil society organisations.

\section{REFERENCES}

AgOSÍN, M.R. and TUSSIE, D. (eds.) (1993) Trade and Growth: New Dilemmas in Trade Policy. London: Macmillan.

AMSDEN, A. (1997) “Editorial: Bringing Production Back In — Understanding Government's Economic Role in Late Industrialization”, World Development 25 (4): 469-480.

AMSDEN, A. (2001) The Rise of the Rest: Challenges to the West from Late Industrializing Economies, Oxford: Oxford University Press.

BRESSER-PEREIRA, L.C. and NAKANO, Y. (2003) "Crescimento Econômico com Poupança Externa?”, Brazilian Journal of Political Economy 23 (2) (90): 3-27.

CALVO, G.A. (1996) "The Management of Capital Flows: Domestic Policy and International Cooperation”, in G.K. Helleiner (ed.) The International Monetary and Financial System. London: Macmillan.

CALVO, G.A., LEIDERMAN, L. and REINHART, C. (1996) "Inflows of Capital to Developing Countries in the 1990s". Journal of Economic Perspectives 10 (2), Spring: 123-139.

CHANG, H.-J. (1994) The Political Economy of Industrial Policy, London: Macmillan.

CHANG, H.-J. (2002) Kicking Away the Ladder?: Policies and Institutions for Economic Development in Historical Perspective. London: Anthem Press.

CORNIA, G., Jolly, R. and STEWART, F. (1988) Adjustment with a Human Face: Protecting the Vulnerable and Promoting Growth. Introduction and chapters 1, 6.

DAGDEVIREN, H., VAN DER HOEVEN, R. and WEEKS, J. (2002) "Poverty Reduction with Growth and Redistribution", Development and Change 33 (3): 383-413.

EPSTEIN, G., GRABEL, I. and JOMO K.S. (2003) "Capital Management Techniques in Developing Countries: An Assessment of Experiences from the 1990's and Lessons For the Future”, XVI Technical Group Meeting of the G-24, Port of Spain.

FELDSTEIN, M. and HORIOKA, C. (1980) "Domestic Savings and International Capital Flows", Economic Journal 90 (358): 314-29.

GEREFFI, G. and WYMAN, D.L. (1990) Manufacturing Miracles: Paths of Industrialization in Latin America and East Asia. Princeton: Princeton University Press. 
MACEWAN, A. (1999) Neo-Liberalism or Democracy? Economic Strategy, Markets, and Alternatives for the 21 $1^{\text {st }}$ Century. London: Zed Books.

MILANOVIC, B. (2002) “True World Income Distribution, 1988 and 1993: First Calculation Based on Household Surveys Alone”, Economic Journal 112: 51-92.

PALMA, G. (1998) “Three and a Half Cycles of 'Mania, Panic and [Asymmetric] Crash': East Asia and Latin America Compared", Cambridge Journal of Economics, 22(6): 789-808.

RAO, J.M. (2002) The Possibility of Pro-Poor Development: Distribution, Growth and Policy Interactions, manuscript.

SAAD FILHO, A. (2003) Democratic and Pro-Poor Economic Strategies for Developing Countries: an Overview. VIII Encontro da Sociedade Brasileira de Economia Política, Florianópolis.

SUPLICY, E.M. (2003) “Renda Básica: A Resposta Está Sendo Soprada pelo Vento”, Brazilian Journal of Political Economy 23 (2) (90): 47-62.

UNDP (2003) Making Global Trade Work for People. Geneva: UNDP.

WINTERS, L.A. (2002) “Trade Policies for Poverty Alleviation”, in B. Hoekman, A. Mattoo \& P. English (eds.) Development, Trade, and the WTO. Washington D.C.: The World Bank. 